2016

The university as a site of socialisation for sustainability education

winter, J::0000-0003-1713-3988

http://hdl.handle.net/10026.1/5720

10.1007/978-3-319-32928-4_7

Springer Link

All content in PEARL is protected by copyright law. Author manuscripts are made available in accordance with publisher policies. Please cite only the published version using the details provided on the item record or document. In the absence of an open licence (e.g. Creative Commons), permissions for further reuse of content should be sought from the publisher or author. 
This is an Accepted Manuscript of an article published by SpringerLink in the book Teaching Education for Sustainable Development at University Level edited by Walter Leal Filho and Paul Pace, available at: http://link.springer.com/chapter/10.1007\%2F978-3-319-32928-4 7

\title{
The university as a site of socialisation for sustainability education
}

\author{
Dr Jennie Winter, Professor Debby Cotton and Dr Paul Warwick \\ PedRIO, Plymouth University, 3 Endsleigh Place, Drake Circus, Plymouth. PL4 8AA, UK \\ Email: jennie.winter@plymouth.ac.uk
}

\begin{abstract}
This chapter reports on an innovative approach to in-service teacher education focusing on Education for Sustainable Development (ESD) aimed at faculty in a UK university. Building on the underpinning philosophies that characterise sustainability education: participation, experiential learning and authenticity, a module on ESD was designed which at first flipped and then moved beyond the classroom.
\end{abstract}

An online resource was developed to house the necessary declarative content which student-teachers accessed before the class. Class time was then spent within deliberative, dialogic and 'walkabout' learning spaces. These included a critically informed tour of the university campus and community exploring the 'unseen university', following energy and waste processes, evaluating accessibility and inclusivity and considering the university as an example of an organisation in transition. They also afforded the opportunity for studentteachers to meet key sustainability individuals from procurement, estates, marketing and finances, as well as curriculum champions and of course students themselves.

Discussions took place in boiler rooms, on stairwells, in coffee shops and in parks. Following an action research strategy for change leadership, student-teachers collaboratively and critically dissected these experiences and negotiated assignments which were not only informed by these experiences but that sought to address specific sustainability needs identified on our journeying through the university as a manifold learning space.

At the end of the course, student-teachers used the UNECE (2012) framework for Competences in Education for Sustainable Development to assess what had been learnt and where to focus ongoing CPD. The course has proved popular in its home institution and has been showcased as an example of good practice by the European Communion through their 'Lifelong Learning Programme' (Mader et al. 2014).

\section{Introduction}

The United Nations 'Decade of Education for Sustainable Development' (DESD) (20052014) has provided a focus for the development of a variety of educational activities around sustainability. The United Nations Educational, Scientific and Cultural Organisation stated that the over-arching goal of the DESD was to integrate the values of sustainable development into all aspects of education and learning in every education sector (UNESCO 2014). In the UK, although support for ESD in Higher Education (HE) has been both spatially and temporally piecemeal, there is evidence both of demand from students (Drayson et al. 2012), and enthusiasm from staff (Cotton et al. 2007). The Higher Education Funding Council for England produced its first sustainability policy and strategy in 2005 (HEFCE 2005) and although later HEFCE publications were somewhat less wholeheartedly supportive of sustainability in the curriculum, the UK Quality Assurance Agency have also taken up the mantle, producing a Guidance document for UK HE providers on ESD (QAA 2014). Thus, sustainability issues have been moving towards the mainstream of academic discussions, aided by the development of People and Planet's 'Green League', which has reported annually 
This is an Accepted Manuscript of an article published by SpringerLink in the book Teaching Education for Sustainable Development at University Level edited by Walter Leal Filho and Paul Pace, available at: http://link.springer.com/chapter/10.1007\%2F978-3-319-32928-4 7

since 2007, and the rapid growth of the 'Green Gown Awards' (reflecting ESD innovation amongst other aspects of sustainability).

However, despite a global movement that has highlighted the need for sustainable development and emphasised the role that HE could play - through research, improving environmental management on campuses, and ESD (Sterling et al. 2013. Wals 2014), progress in campus greening continues to be more rapid - and less contested - than embedding sustainable development in the HE curriculum (Tilbury 2011). The reasons for the slow pace of change in teaching and learning have been widely discussed in the literature, and a key limiting factor is expertise of teaching staff and conceptual confusion. Research has established that both staff and students struggle to understand the range of the term, 'sustainability', focusing primarily on the environmental dimensions rather than integrating this with social and economic aspects (Bone and Agombar 2011. Kagawa 2007). In addition, there are considerable difficulties associated with helping students to develop the personal and social capacities which are important in ESD, especially when desired outcomes are complex and unpredictable (Cotton et al. 2012). Perhaps because of these barriers, there is little evidence that ESD is routinely embedded across HE curricula or in academic staff development programmes - although clearly pockets of good practice in both exist.

In order to prompt a step-change in ESD activities within HE, considerable efforts need to be expended in the sphere of teacher education aimed at in-service HE teaching staff (often termed faculty development or educational development). Innovative practices are needed to overcome the limited perspectives of ESD commonly constrained by disciplinary silos. The emergent nomenclature around sustainability, sustainable development and ESD suggest these are contested conceptual territories tightly constrained by socio-political geographical context (Blewitt 2008). However, increasing consensus that ESD is an important vehicle for pursuing sustainability has emerged and over time greater understanding of the cultural implications of sustainability has led to opportunities for innovation. Educators have started to move away from the confines of positivist, transmissive forms of pedagogy to explore interpretivist and socially critical approaches which better engender the characteristics of a sustainability orientated population (Robottom and Hart 1993); declarative and metacognitive competencies, self-reflection and awareness of the inter-connectedness of human and natural systems (Sterling 2004). In an HE context, this involves the development of systemic and epistemic thinking skills; responses that transcend discipline and other models of institutional organisation and call for institutional and organisational transformation founded on participation, experiential learning and authenticity (Winter et al. 2015).

The significant consequences of such a change in perspective - were it to be widely adopted - indicate the need for increasing support for HE educators tasked with enthusing and creating a sustainability-cognisant graduate population. As well as suggesting a shift in pedagogic approach, there are increasing international efforts to generate taxonomies of knowledge, values and skills which can be used as measurable outcomes of ESD across disciplinary divides. In the UK these are commonly referred to as 'literacies' and salient examples have been developed by scholars including Dawe, Jucker, and Martin 2005; Parkin et al. 2004 and Stibbe and Luna 2009. Underpinning these taxonomies are ideas about appropriate educator aptitudes and capabilities (Mader et al. 2014. Willy 2008). In the UNESCO report 'Learning: the treasure within', Delors et al (1996) recognize four pillars for education of 21 st Century: learning to know, learning to do, learning to be and learning to live together. These have been re-worked as a framework of competencies for educators in ESD by UNECE (2012) (Box 1) and have been widely communicated throughout the global HE sector. 
This is an Accepted Manuscript of an article published by SpringerLink in the book Teaching Education for Sustainable Development at University Level edited by Walter Leal Filho and Paul Pace, available at: http://link.springer.com/chapter/10.1007\%2F978-3-319-32928-4 7

Box 1 Competencies for educators in ESD (abridged version - full model available at http://insight.glos.ac.uk/sustainability/Education/Pages/UNECE.aspx)

Learning to know

Learning to do

Learning to be

Learning to live together
Holistic approach

Envisioning change

Achieving transformation
Integrative thinking and practice

Past, present and future

People, pedagogy and education system

In UK HE, however, calls for ESD educator competencies must compete with other drivers for enhancing teaching quality, as well as the potentially conflicting interests of research and enterprise. Awareness of the value of continuing professional development (CPD) for teachers in HE has increased in response to a changing landscape motivated in part by policy developments and paralleled by changes to fee structures which position students as 'consumers' of HE. This has led to the growing provision of faculty or educational development in UK Higher Education Institutions (HEIs) which consists of a range of activities including introducing new lecturers to 'best' practice in teaching and learning, to pedagogic activities and themes, and to pedagogic research. As yet there is no nationally recognised mandatory accreditation of new university educators although recognition opportunities do exist through organisations like the Higher Education Academy (HEA), the professional association for Staff and Educational Developers (SEDA) and various other bodies. Provision and content of teaching-related CPD - including consideration or embedding of ESD - is currently dependent on local institutional priorities and the capacity/willingness of the CPD provider.

\section{The Plymouth Context}

Throughout the UNDESD, Plymouth University has worked towards becoming an international leader in ESD at HE level. In 2005 the University benefited from significant funding from HEFCE and was able to establish the Centre for Sustainable Futures (CSF) as a Centre for Excellence in Teaching and Learning in ESD. The CSF built on well-established ESD research and teaching practice at Plymouth University in order to advance ESD through an integrated approach to curriculum innovation. It developed a holistic model for whole institutional change that has been referred to as the $4 \mathrm{C}$ 's model of Campus, Curriculum, Community and Culture. From its start, the bold vision of the CSF has been to "develop a strategy and activities that could transform the university towards a state where sustainability permeated the curricula, physical campus, and the whole institutional culture" (Sterling et al. 2013 p41). Pursuing this vision has led to a range of positive steps towards the sustainable university including the creation of the University's sustainability strategy in 2008. CSF has been able to serve as a hub supporting a wide variety of faculty from across all departments in pioneering curriculum change and associated research. More recently it has also resulted in a range of ESD initiatives co-developed with or led by students.

Over the last ten years Plymouth's ESD reputation both nationally and internationally has grown, with numerous awards and accolades received by the institution and individual staff members for their pioneering contribution to teaching and learning. Most recently in 
This is an Accepted Manuscript of an article published by SpringerLink in the book Teaching Education for Sustainable Development at University Level edited by Walter Leal Filho and Paul Pace, available at: http://link.springer.com/chapter/10.1007\%2F978-3-319-32928-4 7

2014 Plymouth University was recognised as the top UK institution in the People and Planet Green League and was also awarded three Green Gown Awards by the Environmental Association for Universities and Colleges (EAUC), in recognition of exceptional sustainability initiatives.

Throughout this time, internal reviews have highlighted the vital role of a broad suite of CPD opportunities for academic staff in ESD. Increasingly emphasis has been placed on training that engages staff in apt ESD pedagogies; supporting the active, participatory, experiential and interdisciplinary engagement of students (Peterson and Warwick 2015). Within this aspect of work it has also been recognised that it is vital that formal and accredited pathways are provided for new staff to engage in ESD. This leads us to innovative work in the area of Educational Development.

There is a long history of Educational Development at Plymouth which is manifest in the current offer of an accredited teaching course for new lecturers, the Postgraduate Certificate in Academic Practice (PGCAP). This is a level 7 course which consists of a core module (30 credits) and either a pedagogic research module (30 credits) or two 'Negotiated Study Modules' (NSM) at 15 credits each (20 hours contact time and a further 180 hours independent study time). The NSM is an umbrella module which houses a range of important HE topics which share learning outcomes and quality assurance processes but differ in terms of content. This is where the ESD Module discussed in this chapter sits, which inevitably impacts on how it has been conceptualised: for example, the learning outcomes (Box 2) are necessarily generic to allow for the diversity of the topics studied through the NSMs, and the negotiated element of the module means that students have an input into the assessment criteria and format for their assignment.

Box 2 Learning outcomes for the ESD Negotiated Study Module

- Identify an appropriate topic and explain its significance in relation to academic or professional practice

- Construct theoretically-informed arguments about the topic and critically analyse its relationship to academic or professional practice

- Generate new ideas or connections and reflect on their impact on your own academic or professional practice earning outcomes

\section{The Sustainability Education Negotiated Study Module}

The module was initially designed to provide an introduction and toolkit for the new educator interested in embedding sustainability into their teaching and student learning. The learning outcomes were addressed through a series of topics around which teaching was organised:

- Introduction to the historical context of ESD and its diffusion through to contemporary policy and practice in HE.

- Exploring different paradigms and positions.

- Learning theories and pedagogy; exploring experiential, transformative, individual and social approaches.

- Implementation; critically evaluate whole institution responses, the formal, informal and campus curricula and interdisciplinarity.

The first year the module ran it was taught in a classroom, using PowerPoint to convey information to participants but with a heavy emphasis on peer discussion to share knowledge and ideas about the content. The module was therefore interactive to some extent; students led elements of the discussion and were instrumental in choosing the form of assignment, however, despite being offered the opportunity to select an alternative form of assessment, 
This is an Accepted Manuscript of an article published by SpringerLink in the book Teaching Education for Sustainable Development at University Level edited by Walter Leal Filho and Paul Pace, available at: http://link.springer.com/chapter/10.1007\%2F978-3-319-32928-4 7

they unanimously chose to submit essays. Although participants met the learning outcomes and passed the assessment - questions arose in the tutor's mind about the extent to which content and delivery could be 'transformed' within the context of the current system. This motivated a process of reflection and curriculum change which began with considering the module's learning outcomes, content, teaching/learning activities and assessment criteria to ascertain the extent to which these were constructively aligned (Biggs and Tang 2007). It was recognised through this process that the philosophies underpinning the content of the module sat uneasily with the pedagogies employed in its delivery; there was little to differentiate the delivery from traditional HE pedagogy or to align it with the philosophical and applied underpinnings of ESD. Where there had been opportunities for risk taking and modelling good practice there were instead tensions and dissonance. This formed the basis for curriculum change, the aim of which was to reflect better the principles of ESD in the module teaching.

Through considering the literature about educator competencies and sustainability literacies, we decided to align the content of the module with the underpinning philosophies of ESD. The existing academic content would be used to underpin a pedagogic approach which utilised the University campus and operations to provide an immersive experience encompassing the critical elements of 'learning to know, learning to do, learning to be and learning to live together' (Delors et al. 1996). The university is an excellent example of an organisation in sustainability transition (Jones et al. 2010) and includes elements which are successfully drawn together - as well as those which remain in tension. In effect, the campus was utilised as the classroom and provided authentic learning opportunities arising out of participant interactions with their environment through a genuine, exploratory and situated experience. Although fieldwork is an oft-utilised pedagogy in HE (Hill and Woodland, 2002) the university campus and organisation are not commonly used as vehicles for learning. However, using the campus as a way of building on existing connections to place can provide an enhanced learning experience. "Place is ... a way of seeing, knowing and understanding the world. When we look at the world as a world of places we see different things. We see attachments and connections between people and place (Cresswell 2004 p11)." Kagawa (2007 p320) suggests the campus as a possible catalyst for exemplifying "the interconnectedness of social, economic and environmental interests creating a "sustainability orientated pedagogy of place." The campus can provide a subject-neutral forum through which sustainability can be experienced, discussed, critiqued and reflected upon regardless of the "limitations of [disciplinary] tunnel vision (Jucker 2002 p13)."

In moving out of the classroom and into the campus environment, an alternative pedagogic approach was needed. In this example, the new model drew on recent developments focused on 'flipping' the classroom (Berrett 2012. Mazur 2009) where participants gain first-exposure learning prior to class and focus on the processing part of learning (synthesizing, analysing, problem-solving, etc.) in class with the support of peers and the tutor (Brame ND). The content that had informed the original lectures was used to create a series of online resources in 'Xerte' (Nottingham University ND) which presented information relevant to the learning outcomes. The resource also presented interactive activities which the tutor linked to the face-to-face sessions. These activities encouraged participants to engage prior to the sessions, and come prepared with some content knowledge, questions and comments. (This resource has also been used by academics at Plymouth and beyond as a stand-alone introduction to ESD).

The face-to-face sessions were then freed up to pursue the holistic and experiential introduction to Plymouth University as a sustainability community. This was undertaken through a series of meetings, discussions and activities as presented in Box 3. Participants 
undertook pre-class activities which helped them prepare for the sessions. The first part of the teaching session was used to discuss new knowledge and place it into the Plymouth context by designing questions and themes to use with the significant individuals and activities that were scheduled for the day. Discussions with university staff took place in situ depending on the individual and theme, so for example the discussion with the Head of Estates took place on a tour of the university taking in boiler rooms, kitchens, recycling and waste facilities etc. The Student Union officer was met in the Student Union where a tour of progress in sustainability took place including a coffee and chat with students involved in sustainabilitythemed volunteering. Sometimes we made it back to the classroom to regroup and reflect; sometimes we did this in coffee shops or corridors. As we explored the university we observed the formal informal and hidden aspects of the sustainability curriculum (Cotton et al. 2013. Winter and Cotton 2012. Winter et al. 2012) and the day always ended with a reflective discussion to summarise our experiences and prepare next steps.

Box3 Detail of flipped classroom by teaching theme

\begin{tabular}{|c|c|}
\hline Pre-class activity & In-class activity \\
\hline $\begin{array}{l}\text { Introduction to the historical } \\
\text { context of ESD } \\
\text { Xerte URL - } \\
\text { https://xerte.plymouth.ac.uk/play.php? } \\
\text { template_id=292 }\end{array}$ & $\begin{array}{l}\text { Significant Individuals- } \\
\text { - Head of ESD in the curriculum - Stephen } \\
\text { Sterling*/ Paul Warwick* } \\
\text { - } \text { Educational Developers - Lynne Wyness* } \\
\text { Debby Cotton* Jennie Winter* }\end{array}$ \\
\hline $\begin{array}{l}\text { Background research on significant } \\
\text { individuals and roles in the university } \\
\text { Suggested reading } \\
\text { Xerte activities }\end{array}$ & $\begin{array}{l}\text { In-class activities - } \\
\text { - } \\
\text { Defining Sustainability Exploring } \\
\text { - } \\
\text { - SD in HE - strengths and weaknesses } \\
\text { Visiting the Centre for Sustainable Futures }\end{array}$ \\
\hline $\begin{array}{l}\text { Exploring different paradigms and } \\
\text { positions on ESD } \\
\text { Xerte URL - } \\
\text { https://xerte.plymouth.ac.uk/play.php? } \\
\text { template_id=384 } \\
\text { Background research on significant } \\
\text { individuals and roles in the university } \\
\text { Suggested reading } \\
\text { Xerte activities }\end{array}$ & $\begin{array}{l}\text { Significant individuals - } \\
\text { - Head of ESD in the curriculum } \\
\text { - Paul Murray* author of 'The Sustainable } \\
\text { - Self' (Murray 2011) } \\
\text { In-class activities - } \\
\text { - Exploring personal values and their impact } \\
\text { - } \text { on teaching } \\
\text { - Discussing links between content and } \\
\text { pedagogy } \\
\text { Personal reflection on competencies as an } \\
\text { ESD educator (UNECE 2012) }\end{array}$ \\
\hline $\begin{array}{l}\text { Learning theories and pedagogy** } \\
\text { Xerte URL }- \\
\text { https://xerte.plymouth.ac.uk/play.php? } \\
\text { template_id=417 } \\
\text { Background research on significant } \\
\text { individuals and roles in the university } \\
\text { Suggested reading } \\
\text { Xerte activities }\end{array}$ & $\begin{array}{l}\text { Significant individuals - } \\
\text { - Head of ESD in the curriculum } \\
\text { - Previous students } \\
\text { - Student Union Environmental Officer } \\
\text { In class activities - } \\
\text { - Designing curriculum change - taking } \\
\quad \text { current teaching practice and making more } \\
\quad \text { sustainable }\end{array}$ \\
\hline
\end{tabular}




\begin{tabular}{|c|c|}
\hline & $\begin{array}{l}\text { - Teaching outside - moving the classroom to } \\
\text { the park - benefits and disadvantages } \\
\text { - Making connections with the informal } \\
\text { curriculum - designing links with student } \\
\text { groups } \\
\text { - Walkabout of university making videos of } \\
\text { evidence of sustainability and exploiting } \\
\text { learning opportunities }\end{array}$ \\
\hline $\begin{array}{l}\text { Implementation** } \\
\text { Xerte URL }- \\
\text { https://xerte.plymouth.ac.uk/play.php? } \\
\text { template_id=297 } \\
\text { Background research on significant } \\
\text { individuals and roles in the university } \\
\text { Suggested reading } \\
\text { Xerte activities }\end{array}$ & $\begin{array}{l}\text { Significant individuals - } \\
\text { - } \text { Sustainability Manager } \\
\text { - Head of Estates } \\
\text { - Head of Procurement } \\
\text { - } \text { Student Union Environment Officer } \\
\text { - Students } \\
\text { In class activities - } \\
\text { - Walkabout of university visiting boiler } \\
\text { rooms, waste processing plant/ catering } \\
\text { sites/student union/ outdoor learning spaces/ } \\
\text { institute supporting sustainability research } \\
\text { with relevant significant individuals } \\
\text { discussing links between the different } \\
\text { processes, event and activities } \\
\text { - Working in interdisciplinary teams to } \\
\text { develop briefs for teaching sustainability } \\
\text { together } \\
\text { - Analysing how the University markets its } \\
\text { sustainability credentials alongside other } \\
\text { competing agendas }\end{array}$ \\
\hline
\end{tabular}

*Names have been attributed to roles where these individuals have made a contribution to ESD literature of interest to the reader.

**These elements were supported by Sterling (2012), Winter (2015) and Winter et al. (2015).

Through provision of content, activities and discussions, participants were able to gain an understanding of the strengths, weaknesses, links and complexities inherent in creating and maintaining a sustainability university and link this to curriculum opportunities. This better aligned ESD and academic development highlighting that "In general, good sustainable development pedagogy is often simply good pedagogy (HEFCE 2008 p34)," and provided participants with first-hand experience of the sustainability community of the university. Assignments became much more innovative and applied, and students were encouraged to consider submitting alternative assessment formats by a formative assignment which tasked them with making a short video about their position on sustainability education 
and what it meant for their teaching. Video is a useful way to capture and discuss learning and is increasingly accessible to students through the ubiquity and affordability of personal technologies (Attwell and Hughes 2010).

The videos were uploaded to the Digital Learning Environment (Moodle) where an online discussion about each one took place with critical commentary provided to guide final submissions. Summative assignments were much more varied and included; the redesign of a programme in architecture, a music concert using a junk orchestra, a conference presentation, a briefing paper on using the campus for learning in Geography and a draft journal article.

The module is now in its fourth year and continued evaluation has generated evidence about strengths and weaknesses. Feedback from students has been very positive, with satisfaction for the module consistently high (100\%) as is participant engagement and perceived contribution to professional development (both 100\%). Participants have offered the following statements:

- 'This course enabled me to integrate sustainability as part of the curriculum'.

- 'Interviewing and interacting with key stakeholders across Plymouth University had the most significant impact on me'.

- 'The module helped me to approach pedagogy and research in a much more interdisciplinary way and to learn from others' experiences'.

- 'The module opened my eyes, it was lively and real, it was not process driven and unrelated to real people'.

- 'Doing the video prep for this module encouraged me to set a podcast for 100 students which I would not have done otherwise'.

- 'It was wonderful to have some freedom in the assignment'.

- 'Group formative discussion, based on videos produced by NSM students, led to something of an epiphany. It became clear that, in interdisciplinary interactions around sustainability, involving my own discipline requires the twofold case to be clearly made that: philosophical realism is indispensable to engineering and the physical sciences; but philosophical realism does not inevitably mean a positivist epistemology, with all the difficulties that the latter would raise for experts in the humanities and social sciences'.

- 'Writing the assignment has helped in an ongoing process of clarifying my thinking about how undergraduate teaching in fluid mechanics can be rearrange to make available information on the use, for building ventilation and other fluid delivery systems, of renewable energy sources, particularly the buoyancy associated with naturally-occurring temperature differences and with waste heat from machinery, as an alternative to turbo-machinery powered by grid electricity. As a result, I now believe I may be able to implement this reform in time for delivery in stage 4 in the 2016-2017 academic year'.

In addition to this positive feedback it is evident that many students went on to undertake other ESD-related CPD including attending conferences, running workshops and publishing papers. However, tutor reflections and participant feedback have also led to recommendations for future change. For example, at present participants elect to take the module and so engagement with the ESD agenda remains largely optional. This could be addressed by articulating the close links between ESD and academic development within the core offer. In addition, more work with experienced academics and teaching teams with regard to embedding sustainability across the curriculum is planned and in progress. Working with staff at a range of levels within the institution is important to ensure that change is not left to lone enthusiasts and that those faculty inspired by the ESD module are supported to make 
further changes to the curriculum. Finally an area for future development is for the CSF to be more involved in the delivery of this module so that relationships between CSF and new lecturing staff are formed and the suite of CSF funding, resources and personnel to support future research and innovation are made more easily accessible to the participants once they have completed the course.

\section{Conclusion}

UNESCO's Global Action Plan for ESD, following on from the UNDESD, continues the call for universities to lead on the sustainability agenda and emphasises the ongoing need for whole institutional change. This chapter has argued that a key aspect in this mandate to transform the university towards sustainability is teacher education aimed at new and existing HE teaching staff. As highlighted by the UNECE (2012), ESD requires educators to have a broad range of competencies that are not easily or quickly developed. At Plymouth University our experiences have revealed the importance of HE professional development opportunities that embody the participatory, experiential and interdisciplinary pedagogical approaches that are congruent with the aims of ESD. Focusing on a specific accredited ESD teacher education module we have seen the value of changing the very fabric of the course so that its aims and content could shift from an academic perspective on ESD to a holistic, systemic and experiential introduction to the University as a sustainability community and an organisation in sustainability transition. It has encouraged module participants to engage in ESD as 'critical creatives'; identifying where and how their teaching, and more importantly their students' learning, could contribute to the University moving ever closer towards its sustainability aspirations.

\section{References}

Attwell G. and Hughes J. (2010). "Pedagogic Approaches to Using Technology for Learning: Literature Review”. Lifelong Learning UK. http://webarchive.nationalarchives.gov.uk/20110414152025/http:/www.lluk.org/wpcontent/uploads/2011/01/Pedagogical-appraches-for-using-technology-literaturereview-january-11-FINAL.pdf (Last accessed 20/05/2015)

Berrett D. (2012). "How 'flipping' the classroom can improve the traditional lecture". The Chronicle of Higher Education, Feb. 19, 2012.

Biggs J. and Tang C. (2007). Teaching for Quality Learning at University. 3rd edition. Open University Press, Maidenhead.

Blewitt, J. (2008). Understanding Sustainable Development. Earthscan, London.

Brame C. (ND) "Flipping the Classroom". http://cft.vanderbilt.edu/guides-subpages/flipping-the-classroom/ (Last accessed 29/05/2015)

Bone E. and Agombar J. (2011). "First-year attitudes towards, and skills in, sustainable development". Higher Education Academy, York.

Cotton D., Warren M., Maiboroda O. and Bailey I. (2007). "Sustainable Development, Higher Education and Pedagogy: A study of lecturers' beliefs and attitudes". Environmental Education Research, 13, 5, 579-597

Cotton D., Sterling S., Neal V. and Winter J. (2012) Putting the 'S' into ED: Education for Sustainable Development in Educational Development. SEDA Special 31

Cotton, D.R.E., Winter, J. and Bailey, I. (2013) "Researching the hidden curriculum: intentional and unintended messages". Journal of Geography in Higher Education. 37, 2, 192-203

Cresswell T. (2004). Place: a short introduction. Blackwell Publishing, Oxford. 
This is an Accepted Manuscript of an article published by SpringerLink in the book Teaching Education for Sustainable Development at University Level edited by Walter Leal Filho and Paul Pace, available at: http://link.springer.com/chapter/10.1007\%2F978-3-319-32928-4 7

Dawe G., Jucker R. and Martin S. (2005). Sustainable development in higher education: Current practice and future developments. A report for the Higher Education Academy. HEA, York.

Delors, J. et al. (1996). Learning: The Treasure Within. Paris: UNESCO. http://unesdoc.unesco.org/images/0010/001095/109590eo.pdf (Last accessed 29/05/15)

Drayson R., Bone E. and Agombar J. (2012). "Student attitudes towards and skills for sustainable development". NUS/HEA, York. http://www.heacademy.ac.uk/assets/documents/esd/Student_attitudes_towards_and_s kills_for_sustainable_development.pdf (Last accessed 20/05/2015)

Higher Education Funding Council for England (HEFCE) (2005). Sustainable Development in Higher Education. HEFCE, Bristol.

Higher Education Funding Council for England (HEFCE) (2008). Strategic review of sustainable development in higher education in England. HEFCE, Bristol.

Hill J. and Woodland W. (2002). "An evaluation of foreign fieldwork in promoting deep learning: a preliminary investigation" Assessment and Evaluation in Higher Education, 27,6, 539-555.

Jones P., Selby D. and Sterling S. (Eds) (2010). Sustainability Education: Perspectives and Practice Across Higher Education. Earthscan, London.

Jucker R. (2002). Our common illiteracy: Education as if earth and people mattered. Peter Lang, Frankfurt.

Kagawa F. (2007). "Dissonance in students' perceptions of sustainable development and sustainability". International Journal of Higher Education 8, 3, 317-38.

Mader M., Michelsen M., Mader C., Burandt S., Tilbury D., Ryan A., Dlouhá J., Barton A., Dlouhý J., Alba D., and Benayas J. (2014). "State of the Art Report: Mapping opportunities for developing Education for Sustainable Development competences in the UE4SD partner countries". University Educators for Sustainable Development, Cheltenham.

http://www.sustainabilityexchange.ac.uk/files/ue4sd_state-of-the-artreport_final_2.pdf (Last accessed 25/05/2015)

Mazur E. (2009). "Farewell, Lecture?" Science 323: 50-51.

Murray P. (2011). The Sustainable Self. A personal approach to sustainability education. Earthscan; London

Nottingham University. (ND) "The Xerte Project". http://www.nottingham.ac.uk/xerte/index.aspx (Last accessed 02/05/2015)

Parkin S., Johnson A,. Buckland H. and White E. (2004). Learning and skills for sustainable development: Developing a sustainability literate society. HEPS, London.

Peterson A and Warwick P. (2015) Global Learning and Education. Routledge, Oxon.

Quality Assurance Agency (QAA). (2014). Education for sustainable development: Guidance for UK higher education providers. QAA, Gloucester.

Robottom I. and Hart P. (1993) "Research in environmental education: engaging the debate. The Deakin-Griffith Environmental Education Project". Deakin University, Australia.

Stibbe A. and Luna H. (2009). Introduction. in Stibbe A. (Ed) (2009). The handbook of sustainability literacy: Skills for a changing world. Green Books, Totnes.

Sterling S. (2004) 'Higher Education, sustainability and the role of systemic learning', in Blaze Conran P. and Wals A. (eds.) (2004) Higher education and the challenge of sustainability: problematics, promise and practice. Kluwer Academic Publishers, London. pp. 347-348. 
Sterling S. (2012). The future fit framework - an introductory guide to teaching and learning for sustainability in HE. Higher Education Academy, York.

Sterling S., Maxey L., and Luna H. (2013). The Sustainable University: Progress and prospects. London and New York: Earthscan/Routledge.

Tilbury D. (2011) "Higher Education for Sustainability: A Global Overview of Commitment and Progress". In GUNI (ed) (2011). Higher Education's Commitment to Sustainability: from Understanding to Action, Higher Education in the World 4, GUNI: Barcelona. (pp. 18-28).

UNECE (2012). Learning for the future: Competencies in Education for Sustainable Development. UNECE, Geneva.

UNESCO (2014). Shaping the Future we want: UN Decade of Education for Sustainable Development (2005-2014) Final Report. UNESCO, Paris.

Wals A. (2014). "Sustainability in higher education in the context of the UN DESD: a review of learning and institutionalization processes”. Journal of Cleaner Production, 62, 815.

Willy S. (2008). "Competencies for ESD (Education for Sustainable Development) teachers. A framework to integrate ESD in the curriculum of teacher training institutes". CSCT, Brussels.

http://www.unece.org/fileadmin/DAM/env/esd/inf.meeting.docs/EGonInd/8mtg/CSC T\%20Handbook_Extract.pdf (Last accessed 28/05/2015)

Winter J. (2015) "Taking an institutional approach to learning about sustainability". Educational Development, Plymouth University. https://www.plymouth.ac.uk/uploads/production/document/path/3/3410/596109_2613 97 _Steps_to_Taking_an_institutional_approach_to_learning_about_sustainability_b old.pdf (Last accessed 02/05/2015)

Winter J., Barton G., Allison J. and Cotton D. (2015). "Learning Development and Education for Sustainability: what are the links?" Journal of Learning Development in Higher Education. Vol 8.

Winter J. \& Cotton D (2012). "Making the hidden curriculum visible: sustainability literacy in higher education" Environmental Education Research. 18, 6, 783-796

Winter J., Sjerps-Jones H., Dexter B. and Klaff J. (2012). "Informal learning for sustainability”. In Cotton D., Sterling S., Neal V. and Winter J. (Eds) (2012) Putting the ' $S$ ' into ED: Education for sustainable development in educational development. SEDA, London. p27-32

Winter J., Sterling S. and Cotton D. (2015). 7 Steps to Embedding Sustainability into Student Learning. Educational Development, Plymouth University. Available online. https://www.plymouth.ac.uk/uploads/production/document/path/3/3409/595997_2613 96_7_Steps_to_Embedding_Sustainability_into_Student_Learning_1214_BOLD.pdf (Last accessed 02/05/2015) 